\title{
On some points in the Histology of Monocotyledons.
}

\author{
BY
}

JOHN PARKIN, M.A.,

Trinity College, Cambridge.

With Plate XIII.

I. ObServations on the Raphides (Figs. I-I 2).

W ${ }^{H E N}$ recently examining microscopically a number of Monocotyledonous leaves and reserve-organs for the purpose of investigating the occurrence and distribution of carbohydrates in them, I also paid some attention to the raphides so often present, and accumulated certain facts concerning them, some of which are apparently new. It was my intention to make a more complete investigation of this class of calcium-oxalate crystals ; but at present, not having sufficient time at my disposal, it seems worth while to notify the few features that have come under observation.

The word 'raphides,' introduced first by De Candolle, is used to denote bundles of needle-shaped crystals which are arranged generally, but not necessarily, in a parallel manner. Each bundle arises in and occupies a single cell. Such cells I term raphide-cells. Although raphides occur in some Dicotyledons, they are pre-eminently characteristic of Mono-

[Annals of Botany, Vol. XII. No. XLVI. June, 1898.] 
cotyledons, often existing in great abundance in the leaves, stems, and especially the reserve-organs. Raphide-cells are very constant in character, only differing from one another in size and in the length of the individual crystal. The bundle of raphides does not fill the cell-cavity, but is suspended in a mass of mucilage. The nucleus and protoplasm originally present in the developing cell disappear when it is fully formed, as Hilgers ${ }^{1}$ showed in the case of Polygonatum. In tissue preserved in alcohol, the bundle is seen lying in the centre of the cell surrounded by a sheath composed of the precipitated mucilage.

In the genus Iris the typical raphide-cells are absent, but crystal-sacs of a different kind are present. These contain each a large acicular crystal, and possess nuclei and protoplasm, but no mucilage. They have been known for a considerable time, and have been investigated by Hilgers ${ }^{1}$ in two species of the genus. De Bary ${ }^{2}$ also refers to them. What I desire to point out is that intermediate stages occur in certain petaloid Monocotyledons between these two types of crystal-sacs; although in using the term 'intermediate,' I do not want it to be inferred that there is necessarily any genetic relationship between the two. The five cases which I have observed are found in Funkia ovata, Convallaria majalis, Phormium tenax var. atropurpurea, Tritoma Uvaria, and Polianthes tuberosa.

Funkia ovata. Raphide-cells of the usual large type exist in fair abundance in the leaf-lamina and petiole (Figs. I and 2). Besides these, however, there is another kind of crystal-cell, which is more widely distributed in the plant, occurring in the leaves and root-stock. They might, without special attention, be passed over as ordinary raphides. The petiole is a gcod region in which to observe these two forms. By carefully examining transverse and longitudinal sections the differences between the two become very manifest.

${ }^{1}$ Hilgers, Pringsheim's Jahrbücher, Vol. vi, 1867-68, p. 285.

${ }^{2}$ De Bary, Comparative Anatomy of Phanerogams and Ferns, p. I38: he refers to Unger's Anatomie und Physiologie, 1855 . 
In a transverse section certain of the crystal-cells are seen to be of smaller diameter, to contain fewer individual crystals of greater sectional area, and to be without the envelope of mucilage (Fig. 3). They are arranged rather differently, being situated near the xylem, one to three being seen in a section to each bundle; odd ones also occur in the ground-tissue along with the ordinary raphide-cells.

In longitudinal section, the differences are more apparent. The new form of crystal-sac is narrower, and contains from ten to twenty needles of a larger size than the numerous ones composing the raphide-bundles. This type of crystal-sac also possesses both nucleus and protoplasm (Fig. 4).

The raphide-cell averages about $250 \mu$. in length, and the individual raphide about $60 \mu$. The crystal-sac is very little longer than the crystals themselves, which average $100 \mu$., about double the length of the raphide.

Convallaria majalis resembles Funkia closely as regards its crystals, possessing in its leaves both ordinary raphidecells, and sacs containing larger and fewer needles without mucilage. The latter are the more numerous. The roots and rhizomes seem only to have the mucilaginous raphidecells. Hilgers ${ }^{1}$ examined the mucilage of the raphide-cells, but makes no mention of the other kind of crystal-sac. In Polygonatum multiflorum, however, I have not succeeded in finding any type of crystal-cell other than the mucilaginous raphide-cells.

Phormium tenax var. atropurpurea. This plant furnishes a more interesting case. In the leaf the crystals which attract attention are very similar to those found in Iris, being solitary prisms in cells without mucilage arranged in longitudinal rows (Figs. 5 and 6). Careful observation, however, also shows here and there ordinary raphide-cells. These are very sparsely scattered. The others are comparatively common, and odd ones contain two crystals instead of the usual solitary one (Fig. 7). 
Tritoma Uvaria. In this plant none of the ordinary mucilaginous raphide-cells could be found either in the root, stem, or leaf; but the other kind are numerous, varying considerably in size, from $60 \mu$. to $160 \mu$. in length. The crystals, which almost fill each sac, are fairly abundant. Nuclei and protoplasm can also be made out in them (Figs. I I and I2).

Polianthes tuberosa. The tuber only has been examined, and in it are found both kinds of crystal-cells. The mucilaginous ones are more numerous and larger (Fig. 10). The others occur chiefly near the vascular bundles (Figs. 8 and 9).

From the fact that these two kinds of crystal-sacs occur in the same plant and even in the same tissue, it looks as if they may have arisen independently, and not have been derived the one from the other. Nevertheless the above instances suggest that as the raphide-cells decrease in number their place is taken by the other type.

In the order Iridaceae raphides seem wholly wanting, only the solitary crystals being present. Besides species of Iris, I have observed these prisms in the genera Crocus, Sparaxis, Schizostylis, Xiphium, Freesia, Babiana, Gladiolus, and Montbretia; and thus they appear characteristic of the order. It may be that the non-mucilaginous crystal-sacs discovered in Funkia, Convallaria, Phormium, Tritoma, and Polianthes are genetically connected with one another and with those of the Iridaceae.

The distribution of special crystal-cells in the large petaloid family, the Liliiflorae, is instructive. The tribes Tulipeae and Allieae are exceptional in containing none ${ }^{1}$. They seem very scarce in the Colchicaceae; Veratrum possesses a few raphide-cells, but I failed to find any in Colchicum or Uvularia. The Iridaceae, as previously shown, possess the large solitary needles. The other groups, as far as I know, contain the ordinary mucilaginous raphide-cells, such as the Hyacintheae, Anthericeae, Yuccoideae, Hemerocallideae,

1 De Bary, loc. cit. p. $\mathbf{I}_{4} 2$. 
Convallarieae, Asparageae, Dracaeneae, Pontederiaceae, and Amaryllidaceae. Then in addition to the ordinary raphidecells, Funkia, Convallaria, Phormium, and Polianthes possess crystal-sacs without mucilage; while Tritoma appears to have the latter only.

Funkia, Phormium, and Tritoma belong to the tribe Hemerocallideae; Hemerocallis fulva and $H$. flava, both of which I have examined, contain ordinary raphide-cells, but not the other type of crystal-sac. The Convallarieae come very near the Hemerocallideae in habit, differing chiefly in the baccate fruit. Thus the four genera, Funkia, Phormium, Tritoma, and Convallaria seem fairly closely allied. Polianthes is placed among the Agaveae, a sub-order of the Amaryllidaceae. It is generally considered that the Amaryllidaceae have been derived from the Liliaceae by the ovary becoming inferior, and sometimes it is inferred that the Iridaceae have arisen from the Amaryllidaceae. It may be that the Iridaceous forms began to appear just about the time the Amaryllideae were evolving, both having a common origin in some Liliaceous type. The similarity of the crystal-sacs would support a relationship between the Iridaceae and the Liliaceous tribe Hemerocallideae.

A special study of these crystals, which are formed in the growing organs, and hence belong to Schimper's class of primary calcium oxalates, might be of value from a phylogenetic point of view, as well as a means of throwing light on their function, of which at present we seem very ignorant.

\section{An ABSCISS-LAyer IN THE LEAves OF Narcissus,}

Galanthus, AND Leucojum (Figs. I3, I4).

Having had occasion to examine species of Narcissus, Galanthus, and Leucojum at various stages in their annual growth, I observed that the foliage does not simply die down and wither away, but that each leaf is detached from its tunicate base (bulb-scale) by means of a layer of cells 
becoming merismatic. Not finding in botanical literature any description of such an absciss-layer in these plants, it seems worth while making a note of it, and pointing out a few details connected with the occurrence.

Von Mohl ${ }^{1}$ in his researches on 'leaf-fall' in reference to Monocotyledons, mentions merely the falling of their perianthsegments and immature capsules.

Bretfeld ${ }^{2}$ has investigated the mode of detachment of leaves in Dracaena, many of the Orchidaceae and Aroideae, and generalizes from the study of these plants, that, whereas the leaf-fall in Dicotyledons is brought about by a new tissue formed a short time before the shedding of the foliage, in Monocotyledons it results from the action of a special mechanism, produced along with the other tissues in the developing leaf, similar to the contrivance which brings about the dehiscence of dry pericarps. However, the method here observed resembles that of Dicotyledons, although it is perhaps simpler in detail.

Some time before the leaves turn yellow, certain of the parenchymatous cells situated a little way above the tunicate base of the foliage-leaf become merismatic, and divide to form a zone of narrow cells with conspicuous nuclei and abundant protoplasm; this region is visible to the unaided eye as an opaque line on holding the leaf up to the light (Figs. I3, I4). In Galanthus nivalis the cell-divisions were just commencing when examined on April 16, and were well advanced on May I ; by the end of May the leaves, having turned completely yellow, are easily detached by means of their absciss-layers from their swollen bases, which now become the scales of the bulb, full of reserve material. The epidermal and mesophyll-cells and nucleated cells belonging to the vascular bundles take part in the divisions; the raphide-cells and, of course, the vessels remain passive, their lumina becoming obliterated by the pressure exerted on them by the adjacent dividing cells. As a rule, about four or

1 Mohl, Botanische Zeitung, 1860.

2 Bretfeld, Pringsheim's Jahrbücher, xii, I880. 
five irregular layers of small narrow cells result from the activity.

In these plants, besides the perfect foliage-leaves, there are sheathing phyllome-structures external to them, the lower parts of which also swell to form reserve bulb-scales, while the upper parts remain membranous and afford a covering to the active region of growth in the young foliage leaves. These upper sheathing parts are likewise divided off from their lower reserve-storing portions by the formation of abscisslayers. These in the case of Galanthus nivalis are well formed by the end of March, that is some time before those of the foliage-leaves.

The plane of detachment is through the middle of the absciss-layer, and previously to the separation the walls of the newly-formed cells become suberised, giving a deep yellow coloration with iodine and sulphuric acid, whereas the other cell-walls stain blue.

The plants in which these absciss-layers have been noticed by me are Narcissus Pseudo-narcissus and N.poeticus, Galanthus nivalis, Leucojum vernum and $L$. aestivum. No doubt other species of these genera exhibit them, and most likely other bulbous Amaryllideae.

Such an absciss-layer, by means of the corky walls formed and by the closure of the vessels, may possibly be a protection against the entrance of Bacteria or fungus-hyphae into the scales, and also a check to the passage of water out of them.

Botanical Laboratory, Cambridge. 


\section{EXPLANATION OF FIGURES IN PLATE XIII.}

Illustrating Mr. Parkin's paper on the histology of Monocotyledons.

Figs. I-I 2 taken from sections, cut from spirit-material and mounted in alcohol, so as to retain the mucilage in the cells. Drawn under a Reichert No. 5, objective.

Funkia ovata-petiole.

Fig. I. Transverse section of a raphide-cell.

Fig. 2. Longitudinal section of the same: $r$. bundle of raphides; $m$. mucilage precipitated by alcohol.

Fig. 3. Transverse section of a crystal-sac with mucilage.

Fig. 4. Longitudinal section of the same: $c$. bundle of acicular crystals; $n$. nucleus ; $p$. protoplasm.

Phormium tenax var. atropurpurea-leaf.

Fig. 5. Transverse section of a crystal-sac without mucilage.

Fig. 6. Longitudinal section of the same.

Fig. 7. Transverse section of a crystal-sac with two crystals : c. solitary crystal.

Polianthes tuberosa-tuber.

Fig. 8. Transverse section of a crystal-sac without mucilage.

Fig. 9. Longitudinal section of the same.

Fig. Io. Longitudinal section of a raphide-cell $: r$. bundle of raphides ; $c$. bundle of acicular crystals; $n$. nucleus ; $p$. protoplasm.

Tritoma Uvaria-root-stock.

Fig. II. Transverse section of a crystal-sac.

Fig. I 2. Longitudinal section of the same: $c$. bundle of crystals; $n$. nucleus; p. protoplasm.

Narcissus poeticus-foliage leaf-base.

Fig. I 3 (natural size). Line $a-b$ shows the position of the absciss-layer; $l$. upper leaf ; s. bulb scale.

Fig. I4. Semi-diagrammatic longitudinal section through region marked $c-d$ in Fig. I3. The absciss-layer in process of formation is shown by the zone of narrow cells recently formed with conspicuous nuclei : $v$. vessel; $r$. raphide-cell; the lumens of both being obliterated by the pressure of the dividing cells; oe. outer or lower, $i e$. inner or upper epidermis. 
1 .

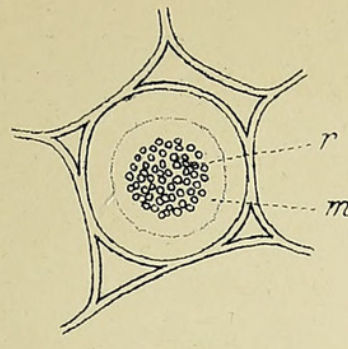

3.

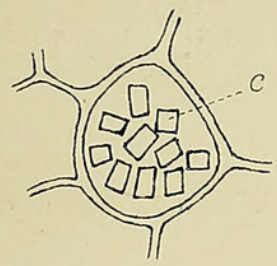

5.

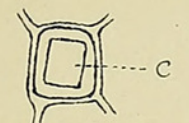

7.

8. 䫿

11.

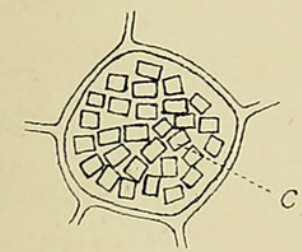

9.

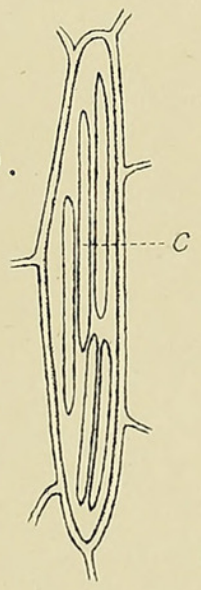

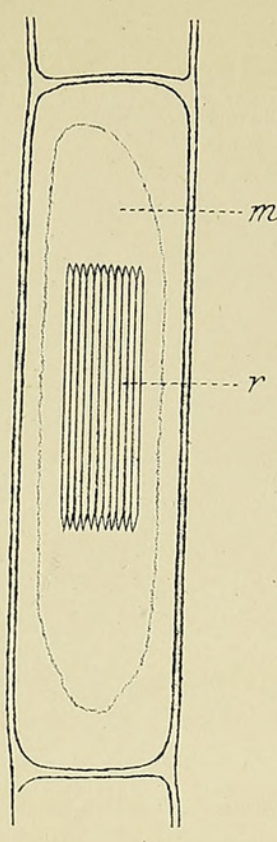

4.
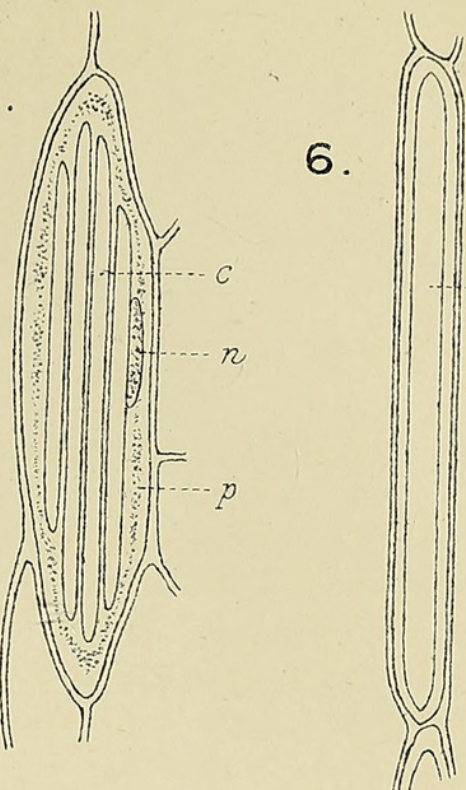
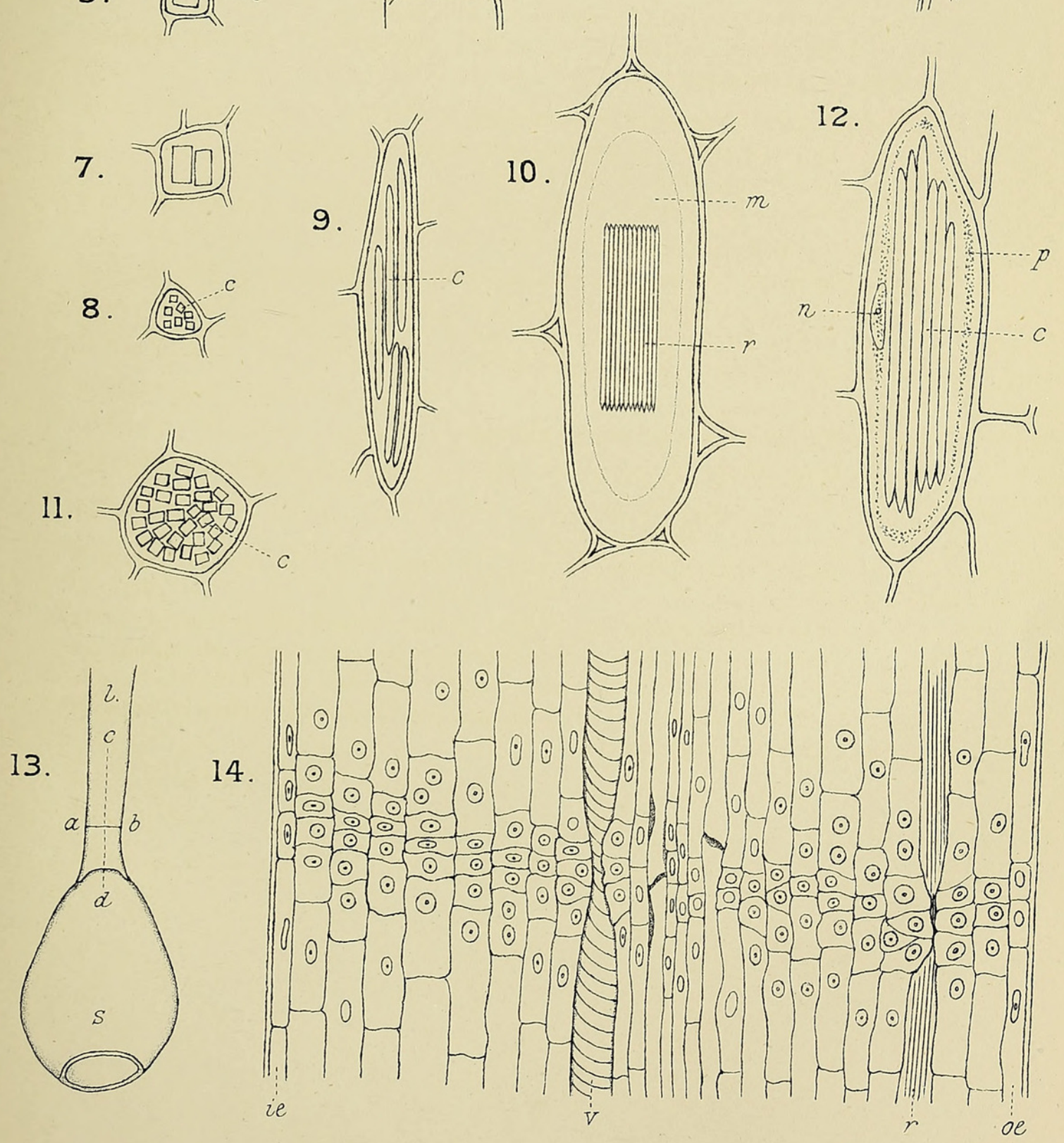

University Press, Oxford.

PARKIN. - MONOCOTYLEDONS. 


\section{$2 \mathrm{BHL}$ Biodiversity Heritage Library}

Parkin, John. 1898. "On some points in the histology of monocotyledons." Annals of botany 12, 147-154.

https://doi.org/10.1093/oxfordjournals.aob.a088687.

View This Item Online: https://www.biodiversitylibrary.org/item/233102

DOI: https://doi.org/10.1093/oxfordjournals.aob.a088687

Permalink: https://www.biodiversitylibrary.org/partpdf/318499

\section{Holding Institution}

Smithsonian Libraries

\section{Sponsored by}

Biodiversity Heritage Library

\section{Copyright \& Reuse}

Copyright Status: Not in copyright. The BHL knows of no copyright restrictions on this item.

This document was created from content at the Biodiversity Heritage Library, the world's largest open access digital library for biodiversity literature and archives. Visit BHL at https://www.biodiversitylibrary.org. 